\title{
COMPARISON OF THE HEALTH TRANSFORMATION POLICIES FOR TURKEY AND UNITED KINGDOM
}

\author{
DOI: 10.17261/Pressacademia.2021.1456 \\ JMML- V.8-ISS.3-2021(4), p.184-196
}

\section{Sezen Tunc ${ }^{1}$, Onur Yarar ${ }^{2}$}

${ }^{1}$ Isik University, Vocational School of Health Sciences, Maslak, Istanbul, Turkey. sezen.tunc@isikun.edu.tr, ORCID: 0000-0002-9372-8169

'Istanbul Okan University, Faculty of Health Sciences, Tuzla, Istanbul, Turkey. onur.yarar@okan.edu.tr, ORCID: 0000-0001-9543-6891

Date Received: July 24, 2021

Date Accepted: September 20, 2021

open 2 access

(cc) BY

To cite this document

Tunc, S., Yarar, O., (2021). Comparison of the health transformation policies for Turkey and United Kingdom. Journal of Management, Marketing and Logistics (JMML), 8(3), 184-196.

Permenent link to this document: http://doi.org/10.17261/Pressacademia.2021.1456

Copyright: Published by PressAcademia and limited licensed re-use rights only.

\section{ABSTRACT}

Purpose- This research was carried out with the aim of comparing the health policies of UK and Turkey periodically. The process of UK entering and leaving the EU from the past until today and the impact of all economic and social events on health policy and the categorical development of health transformation of Turkey from 2002, how the policy of the transformation process was affected and what transformation processes have taken place is the comparison.

Methodology- Before the research, a literature review was made. The study has been concluded by dealing with a wide literature review method on national and international sources. The study is descriptive research and the method of comparing the health policies implemented in certain periods of the two countries from the past to the present has been used.

Findings- The research shows that various health policies have been implemented since the establishment of the Republic of Turkey and that they differ according to these periods. It is seen that England has an important place in the world in terms of health policies and the implementation of these policies, as well as in terms of political and economic findings from the past to the present, especially with the NHS (National Health System) processes, England has reached important levels. NHS's structural features of the National Health System from the past to the present, the administrative and policies that have changed are included.

Conclusion- In this study, the concepts of health were discussed in general and the effect of the changes made in terms of health policies of Turkey and England, which is the main subject of the research, and the current situation and developments in the world were examined. The current situation of Turkey in this field and the development of England has been examined in order to make a comparison. Health services in Turkey and England, which examined in this study, have advantages, disadvantage and risks over each other in different aspects.

Keywords: Health system, health transformation, national health system, UK health system, preventive health services JEL Codes: I10, I18, I15

\section{SAĞLIKTA DÖNÜŞÜM POLITIKALARINDA TÜRKIYE VE INGILTERE KARŞILAŞTIRMASI}

\section{ÖZET}

Amaç- Araştırma, Türkiye ve İngiltere'nin sağlık politikalarının dönemsel olarak karşılaştırılması amacı ile yapılmıştır. İngiltere'nin geçmişten günümüze, $A B$ (Avrupa Birliği)'ye giriş ve çıkış sürecinde, ekonomik ve toplumsal tüm olayların sağlık politikasına etkisi ile Türkiye'nin 2002 yılı itibariyle sağılı dönüşümünün kategorik evrimi ve dönüşüm süreci politikalarının hangi şekillerde etkide bulunduğunu ve hangi dönüşüm süreçlerinin gerçekleştiğinin karşılaştırmasıdır.

Yöntem- Araştırmada önce kaynak taraması yapılmıştır. Ulusal ve uluslararası kaynakların üzerinde geniş bir literatür taraması yöntemi ile çalışma ele alınarak sonuçlanmıştır. Çalışma betimsel bir araştırma olup, geçmişten günümüze iki ülkenin belirli dönemlerde uygulanan sağlık politikalarını karşılaştırma yöntemi kullanıımıştır.

Bulgular- Araştırma, Türkiye Cumhuriyeti'nin kuruluşundan bugüne kadar çeşitli sağlık politikalarının uygulandığını ve bu dönemlere göre farklılık gösterdiğini çalışmalarında görülmektedir. İngiltere'nin ise geçmişten bugüne siyasi ve ekonomik bulgular açısından olduğu kadar sağlık politikaları ve bu politikaların uygulamaları açısından dünyada önemli bir yere sahip olduğunu, özellikle NHS (Ulusal Sağılı Sistemi) süreçleriyle beraber Ingiltere önemli kademelere gelmiştir. NHS'nin geçmişten bugüne Ulusal Sağlık Sistemi'nin yapısal olarak özellikleri, değiştiği yönetimsel ve politikalar yer almaktadır.

Sonuç- Bu çalışmada, sağlık kavramları genel olarak ele alınmış ve araştırmanın ana konusu olan Türkiye ve İngiltere'nin sağlık politikaları açısından yapılan değişikliklerin etkisini ve dünyada ki mevcut durum ve gelişmelere göz atılmıştır. Türkiye'nin bu alanda ki mevcut durumu incelenmiş ve kıyaslama yapabilmek adına İngiltere' nin gelişimi incelenmiştir. Çalışmamızda incelediğimiz Türkiye ve İngiltere sağlık hizmetlerinin farklı açılardan birbirlerine üstünlükleri olduğu gibi, farklı dezavantajlı durumları ve riskleri de bulunmaktadır.

Anahtar Kelimeler: Sağlık sistemi, sağlıkta dönüşüm, ulusal sağlık sistemi, Ingiltere sağlık sistemi, koruyucu sağlık hizmetleri JEL Kodları: i10, i18, i15 


\section{GiRiş}

Sağlık kavramı evrensel bir terim olduğu halde; herkes tarafından kesin olarak kabul edilen bir tanımı bulunmamaktadır. Bu kavramın tanımlanması anlamlandııılması bağıı olduğu kültüre ve tarihsel döneme göre pek çok farklıık göstermiştir.

Sağlık, toplumun diğer kesimlerini de ilgilendiren bir konu olduğu için bu durum kişiye bırakılamaz, sağlık evrensel bir durum olduğundan evrensel insan haklarının en temel maddesidir. Hak ve hukuk olarak değerlendirildiğinde evrensel hukukun birinci değeri sağlıktır. DSÖ (Dünya Sağlık Örğütü)'nün sözleşmesinde geçen tanımına göre; "Sağlık sadece hastalık ve sakatlığın olmayışı değil, bedence, ruhça ve sosyal yönden tam iyilik halidir".

Sağlık hakkı ve sağııkı yaşama hakkı her canlının yaşamının devamını getirebilmesi için en temel değerdir. Bu nedenle sağlık kavramı ülkelerin temel sorumlulukları arasında yer almasına neden olmuştur. Sağlık sisteminin gücü bir ülkenin gelişmişlik düzeyi, yaşam standartlarını, ekonomi gücünü vb. faktörleri belirleyen en önemli güçlerinden biridir. Sağlık sisteminin gücünü, sisteminin düzenini ve işleyiş durumunu belirleyen unsurda o dönemde vurgulanan, sisteme uyarlanmasını sağlayan çeşitli sağlık politikalarıdır. Daha iyi sağlık düzeyi, artan beklentiler, demografik değişimler, teknolojik gelişmeler ve finansal baskılar gibi çeşitli faktörlerin kaynaklık ettiği sağlık reformları, hemen hemen tüm ülkelerde değişim ve gelişim eksenli tartışılmaktadır.

İngiltere, geçmişten bu yana siyasi ve ekonomik veriler açısından olduğu kadar sağlık politikaları ve uygulamaları açısından da dünyada önemli bir yere sahiptir. İngiltere'nin 1948'den günümüze siyasal iktidarların planları ve ekonomik değişimlere bağlı olarak sağıı politikaları değişiklik göstermektedir. Ulusal Sağlık Sistemi kapsamında bireylerin sağlık hizmetleri finansmanının tamamını vergilerden sağlandığı, İngiltere'nin Avrupa Birliği’nden ayrılma süreci ve sağlık politikalarının etkilendiği görülmektedir.

\section{SAĞLIK HIZMETLERI POLITIKALARI VE FINANSMAN MODELLERI}

Politika, bir nüfusta belirli bir durumun, olayın ortaya çıkmasını sağlama veya sınırlama şeklinde ilgili bir makam tarafından verilen bir karardır.

Herkes için sağlık Mayıs 1998'de dünya toplumları tarafından kabullenen ve 1977'de Dünya Sağlık toplantısında ortaya atılmış, 1978 alma-ata toplantısında belirlenen bir politika sunulmuştur. Herkese sağlık politikası 21. yüzyılın ilk 20 yılında bütün dünyada herkesin ulaşabileceği, toplumun önceliklerini ortaya koymak ve en üst seviyede sağlığı hizmetinin erişmesini sağlayacak şartları oluşturmaktır. Ayrıca sağlık politikaları; bireylerin sağlığını yaşamları süresince korumak, onları belirli hastalık ve yaralanmalar ışığına karşı insidans azaltmaktır. Bunların yanında temel insan hakkı olan sağlığı; bölgeler, toplumlar ve kişiler arasında eşitliğini sağlamaktır (Osman vd., 2008).

Sağlık hizmetlerinin üretilmesinde ve yürütülmesinde devlet önemli bir rol üstlenmektedir. Çünkü, sağlık hizmetleri çok karmaşık bir yapıya sahiptir. Sağlık hizmetlerinde talep edilirken bu konuda belirsizlikten dolayı rasyonel bir seçim yapılmamaktadır. Devletin bir başka önemi de sağlık hizmetlerinin bölünmezliğidir ve devlet bunu en iyi şekilde sağlar. Çünkü, özel kuruluşlardan sağlık hizmetleri talebin ve demografik yapının yüksek olduğu yerlerin dışına çıkmamaktadır. Bu da devletin sağlık hizmetleri politikasında bulunmasının önemini arz etmektedir (Selin,2012). Sağlık politikaların en temel unsuru hizmet sunumunun en iyi etki ve düzeye getirilmesidir.

Sağlık hizmetleri son derece önemli bir konudur. Sağlık yönetiminde etki alanı ve uygulanabilirlik kısmı çok geniş olduğu için belirlenecek politikalar son derece etkili olmak zorundadır.

Tablo 1: Uygulanabilir ve Etkili Sağlık Politikasının Unsurları

\begin{tabular}{|l|l|}
\hline Unsur & Gerekçe \\
\hline Görünürlük & $\begin{array}{l}\text { Sağlık probleminin ele alınabilmesi için bu durumun büyüklüğü ve yapısı görünür olmalıdır. Bu durumda } \\
\text { hem veriler etkin analiz edilir, hem de politika belirleyicilerin problemi etkili bir şekilde ifade etmesini } \\
\text { sağlar. }\end{array}$ \\
\hline Kapasite & $\begin{array}{l}\text { Sağlık alanında hizmet verenlerin hem analiz, hem de uygulamada uygun becerilere sahip olmaları } \\
\text { gerekmektedir. Bu durumda sağlık alanında hizmet veren sağlık probleminin görünür olmasını } \\
\text { sağlamaktadırlar. }\end{array}$ \\
\hline Sahiplik & $\begin{array}{l}\text { Sağlık probleminin birden fazla grup tarafından farkında olunması gerekmektedir ki bu durumda bu } \\
\text { problem için politika üretilebilir olmalıdır. }\end{array}$ \\
\hline $\begin{array}{l}\text { Sektöreler arası İş̧ } \\
\text { birliği }\end{array}$ & $\begin{array}{l}\text { Sağlık problemleri genellikle sektörlerarası işbirliğine gerek duyulmalıdır. Sektörlerarası işbirliğin eksik } \\
\text { olması sağlık politikasının sağlıksız kurulmasına neden olmaktadır. }\end{array}$ \\
\hline Etkin Devlet & $\begin{array}{l}\text { Devlet sağlık politikalarında en önemli aktördür. Sağlık politikası noktasında devlet, hem kanun } \\
\text { yapılmasında, hem de uygulamasında yer almaktadır. Bu sürecin zayıf olması sağlık politikasının başarılı } \\
\text { olmasını engellemektedir. }\end{array}$ \\
\hline
\end{tabular}


Görüldüğü gibi, uygulanabilir ve etkili sağlık politikaları: Görünürlük, kapasite, sahiplik, sektörlerarası iş birliği ve etkin devlet olmak üzere beş aşamadan oluşmaktadır. Beş aşamada da belirtilen etkin devlet ilkesi; devletin hem kanun yapılmasında ve hem bu kanunun uygulamasında etkin bir şekilde var olması, aksi taktirde oluşturulacak olan politikanın başarıya ulaşması engellenecektir.

Leys (2007), Bir kamu hizmetini metalaştırmak isteyen ve sağlık hizmetleri politikasını buna göre biçimlendiren konular, sağlık hizmetinden daha önce alınmayan ücretin alınmasına ikna etmek, verilen hizmetin kalitesinin yanında aynı zamanda kâr elde edilen bir ekip haline dönüşmesi ve bu hizmet üretiminde oluşabilecek tüm riskleri devlet tarafına yüklenmesi gerektiği şekilinde görüşünü bildirmiştir.

Toplumun sağ ık hizmetine yönelik beklentilerinin sınırsız olması, buna karşılık sağlık hizmeti için ayrılan kaynakların kısıtlılığı, temel problem alanı olarak ortaya çıkmaktadır. Sağlık hizmetlerinin finansmanı ile ulaşılmak istenen temel amaçlar; toplumdaki tüm bireylerin sağlık hizmetine ulaşmasının sağlanması, yeterli ve kaliteli sağlık hizmetinin sunulması ve sürdürülebilir finansman kaynağının yaratılmasıdır.

Sağlık finansmanının bu amaçları gerçekleştirme sürecinde yerine getirmesi gereken temel işlevler vardır. Bunlar; gelir toplanması, fon havuzlanması ve hizmet sunucularına ödeme yapılmasıdır. Sağlık hizmetlerinin finansmanı da aynı sağlık hizmetlerinin örgütlenmesinde olduğu gibi, ülkelerin tarihinden, kültüründen, ekonomik ve politik yapısından etkilenmektedir.

Sağlık hizmetlerinin finansmanı için kullanılacak model; hakkaniyetli olmalı, kaynakların toplanması aşamasında düşük maliyeti sağlamalı, kaynak akışını devamlı kılmalı, kaliteli hizmet sunumu ve hizmet sunucularının arasındaki rekabeti teşvik etmek ve halkın benimsemesini sağlamalıdır.

Kamu Finansman Kaynakları; vergiler, primler ve özel amaçlı vergiler şeklinde sınıflandırılmaktadır. Özel Finansman Kaynakları; özel sağıık sigortası, toplumsal finansman, işveren finansmanı ve doğrudan (cepten) ödemeler şeklinde başlıca dört başlık altında sınıflandırılmaktadır. Dünyada sağlık hizmetlerinin finansmanı açısından kullanılan, Beveridge Modeli (İngiliz) ve Bismarch Modeli (Alman) olmak üzere iki temel model bulunmaktadır. Diğer modeler olarak, Özel Sigorta Modeli ve Sosyalist Model bulunmaktadır.

Tablo 2: Sağlıkta Finansmanı Tablosu

\begin{tabular}{|l|c|c|c|}
\hline & $\begin{array}{c}\text { Beveridge Modeli } \\
\text { Evrensel Modeli } \\
\text { Kapsayıcı/Bütüncül }\end{array}$ & $\begin{array}{c}\text { Bismarck Modeli } \\
\text { Sosyal Sigorta Modeli } \\
\text { Refah Yönelimli }\end{array}$ & $\begin{array}{c}\text { Özel Sigorta Modeli } \\
\text { Liberal Sağlık Modeli } \\
\text { Özel Teşebbüs/Srb.Pazar }\end{array}$ \\
\hline Finansman/Kaynak & Vergiler & $\begin{array}{c}\text { Çalışan, İşveren Katkısı } \\
\text { (Prim) }\end{array}$ & Özel \\
\hline Hizmet Sunumu & Kamu/Özel & Kamu/Özel & Özel \\
\hline Karar/Yönetim & Devlet & Sigorta fonu, hekim birlikleri & Özel Sigortalar \\
\hline Açıklamalar & $\begin{array}{c}\text { Tüm bireylere yönelik } \\
\text { zorunlu tam kapsamlı }\end{array}$ & $\begin{array}{c}\text { Tüm bireylere yönelik zorunlu } \\
\text { prim ödemeli }\end{array}$ & $\begin{array}{c}\text { Kişisel, Doğrudan ödeme, } \\
\text { isteğe bağlı }\end{array}$ \\
\hline Sistemi Uygulayan Ülkeler & $\begin{array}{c}\text { Almanya } \\
\text { Hollanda } \\
\text { Japonya } \\
\text { Signapur }\end{array}$ & $\begin{array}{c}\text { ABD (Amerika Birleşik } \\
\text { Devletleri) }\end{array}$ \\
\hline
\end{tabular}

Beveridge Modeli: II. Dünya Savaşı sonrasında İngiltere'nin ulusal sağlık sistemini tasarlayan William Beveridge tarafından tasarlanıp, sağlık hizmetlerinin devlet tarafından vergiye dayalı bir şekilde finanse edildiği ve halka sunulduğu bir sağlık sistemidir. Sağlık hizmetinin sunum aşamasından finansmanına kadar gerçekleştirilecek tüm faaliyetlerde kamunun belirleyici bir rol üstlenmesini öngören bir modeldir.

Bismarch Modeli: Üyelerinin sağlık hizmeti ihtiyacını karşılamak amacına yönelik olarak prim toplayan sosyal sigortaların oluşturduğu bir modeldir. Sosyal sigorta kurumlarına üyelik yasal zorunluluk olup, sistemin finansmanı ağırlıklı olarak devlet tarafından düzenlenmekte ve desteklenmektedir. Belirli bir düzeyde özel sektörden söz edilebilmektedir.

Özel Sigorta Modeli: İleri düzeyde endüstrileşmiş ülkeler için, bu sistemin tipik örneği ABD'dir. Hastane yataklarının ve sağlık harcamalarının önemli bir kısmı özel sektördedir. Temel sağlık hizmetleri özel hekimlerce sunulur. Bu sistemde yoksullar ve yaşlılar için geliştirilmiş kamu sigortaları da vardır.

Sosyalist Model: Sağlık hizmetlerinin sunumu ve finansmanı devlet tarafından sağlanır. Koruyucu sağlık hizmetleri ağırlıklıdır. Bu modele örnek olarak Küba sağlık sistemi gösterilebilir. 


\section{TÜRKIYE SAĞLIK POLITIKALARI VE HIZMETLERi}

\subsection{0- 2002 Arası Sağlık Politikaları}

Türkiye'de sağlık reformlarına bakıldığında 1920 meclisinde savaştan yararlananların tedavi, Cumhuriyet Dönemi ile birlikte kurumsallaşmış ve Sağlık Bakanlığı kurulmuştur. Bu dönemlerde önleyici ve tedavi edici hizmetler ve belirli kanunlar çıkartılmıştır. Ayrıca vizyon ve misyonlar belirlenmiştir. Daha sonraki dönemler sağlık devlet tarafından verilmesi gerektiği ve buna göre kurumların kurulması ve sağlık hizmetinin ülkenin her yerine yayılması ileri sürülmüştür.

1946 ve 1960 yılları arasında sağlık hizmeti vermesi tasarlanan sağlık merkezleri açılmış ve hastaneler yerel yönetimlerden Sağlık Bakanlığı'na devir edilmiştir. Yine bu dönemde sağlık ve sosyal güvenlik alanında Hemşirelik Kanunu, İşçi 187 Sigortaları Kanunu vb. yasalar çıkarılmış ve sağlık sisteminin yapılanması bu şekilde devam edilmiştir (Seher,2011). Bu yıllar arasında hastane ve sağlık merkezlerinin ve bunların yatak sayılarının artırılması, sağlık çalışan sayısının artırılması yönünde yapılan çalışmaların yanında sağlık finansman kaynaklarının yapılandırılması ve çeşitli sağlıklı göstergelerini iyileştirmesine yönelik birçok faaliyet yürütülmüş ve çalışmalar yapılmıştır.

1960’। yıllara yaklaşırken sağlık politikaları, anayasa bünyesinde yer alıp kanun hükmü altında vatandaşların sağlık hakları sağlama alınmıştır. Dr. Nusret Fişek; 1960 askeri darbesinin ardından 15 Temmuz 1960 tarihinde Sağlık Bakanlığı Müsteşarlığı'na atanmıştır. Aynı zamanda 224 sayılı Sağlık Hizmetlerinin Sosyalleştirilmesine Dair Kanun'unun da kurucusudur. 1961 yılında çıkarılan 224 sayılı "Sağlık Hizmetlerinin Sosyalleştirilmesi Hakkındaki Kanun", sağlık politikalarına yönelik dönemin en önemli çalışmalarının başında gelmektedir. 1961 yılında kabul edilen bu yasa ile Türkiye'de ulusal sağlık hizmetlerinin oluşturulmasının ilk taşları atılmıştır. 1961 anayasasında, "devlet, herkesin beden ve ruh sağlığın yeterli biçimde yaşayabilmesini ve tıbbi bakım görmesini sağlamakla görevlidir" ifadesine yer verilerek vatandaşların sağıı hakkı tanımlanmasıyla birlikte, bu hakkın gerçekleştirilmesinde devlete görev ve sorumluluklar eklenmiştir. Sağlığın sosyalizasyonuna ilişkin çalışmalar yine bu dönem kapsamında 1963 yılında başlayıp, 1983 yılında ülke geneline yayılması sağlanmıştır (Ünal,2011). Kanun; Cumhuriyet'in ilk yıllarından 1940'lı yılların sonuna kadar ülkemizin sağlık sektörüne damgasını vuran Dr. Refik Saydam'ın ulusal sağlık politikalarından sonra sağlık sektörüne yapılan en büyük kapsamlı ve halkçı müdahaledir.

1980'li yıllara gelindiğinde ise ülkede yeniden düzen hâkim olmaya başlamış ve bundan dolayı sosyal devlet anlayışı çerçevesinde sağlık politikalarına yönelik yeni düşünceler gelişmeye başlamıştır. Bu düşüncelerin ışığında; sağlık hizmetlerinin yayılmasında temel amaç olarak kabullenilmesi, koruyucu sağlık hizmetlerinin öncelikle yeniden yapılandırılması, ana-çocuk sağlığı ile aile planlaması konularında yapılan çalışmalar başlıca önemli çalışmalar olmuştur. Nüfus planlaması ile ilgili sağlık politikaları, GSS (Genel Sağlık Sigortası)'ye ait kanun çalışmaları, sağlık personelinin çalışma düzeni ile ilgili çeşitli sağlık politikaları çalışmaları, hizmet sunumunun uygulanmasına yönelik düzenlemeler de bu dönemde yürütülen sağlık hizmetlerine yönelik faaliyetler arasındadır (Hüseyin vd. 2016).

Türkiye'de özellikle 1980 'le başlayan neo-liberal politikalara eklenme konusunda, bugüne kadar iş başına gelen tüm hükümetler birbirleriyle yarışmıştır. Fakat bu konuda şu ana kadar çıkarılan veya çıkarılması planlanan yasalar ve uygulamalarla en hızlı koşan AKP (Adalet ve Kalkınma Partisi) hükümeti olmuştur.

1993 yılında Sağlık Bakanlığı tarafından hazırlanmış olan, "Ulusal Sağlık Politikası" programı ise; destek, çevre sağlığı, yaşam şekli, sağlık hizmetlerinin sunumu, sağlıklı Türkiye hedefleri olmak üzere bazı temel kısımları içermektedir. Genel anlamda yürütülen sağlık reformalarla, sağlık politikalarına yönelik sağlık alanındaki çalışmaları 4 madde altında toplayabiliriz. Bunlar; "Sosyal güvenlik kurumlarının tek çatı altında birleştirerek GSS'nin kurulması, Birinci basamak sağlık hizmetlerinin aile hekimliği ile geliştirilmesi, hastanelerin özerk sağlık işletmelerine dönüştürülmesi, Sağlık Bakanlığı'nın önceliği koruyucu sağlık hizmetlerine vererek sağlık hizmetlerini planlayıp denetleyen bir yapıya sağlanması" dir.

Bu yıllarda anayasal bir hak olan sağlık kavramına yeterince yer verilmemekle birlikte, sağlık politikalarına da gerektiğinden az önem verildiği gözlenmiştir. En önemli gelişmelerden biri olan sağlık hizmetlerinin sunumunda hastanelerin özelleştirmesi ve hizmet sunumundaki ücret ve geri ödemede ki kurumların oldukça derin değişiklikler hazırlanan sağlık politikalar en önemli konular olmuştur.

\subsection{Yılından Sonra Sağlık Politikalarında Dönüşüm}

2002 yılına kadar çeşitli politik nedenlerden kaynaklı belirlenen ve planlanan durumlar yarım kalmıştır. Turgut Özal döneminde çeşitli adımlar atılmış, özellikle neoliberal sistemden etkilenmiştir. Ancak Turgut Özal'ın ölümü ile uygulananlar yarım kalmıştır. 2002 'den sonra dönüşüm programı ile büyük adımlar atılmaya karar verilmiş ve birçok adım atılmasıyla ilgili maddeler sıralanmıştır. Bu maddelerin en temel bileşenleri; sağlık ve sosyal güvenlik kurumlarının tek çatı altında toplanması, aile hekimiği ve GSS (Genel Sağlık Sigortası)'dir. Bu bileşenlerin yanı sıra, Sağıık Bakanlığı'nın idari ve işlevsel açıdan yeniden düzenlenmesi, koruyucu hekimliğin aktifleşmesine, tüm devlet kuruluşlarında alt kademelere yetki devri, sağlık alanında e-dönüşüm projesinin başlatılması v.b gibi maddeler söz konusudur. 
Bu maddelerin ardından, "SDP (Sağlık Dönüşüm Programı)” hazırlanmış ve 2003 yıllında Sağlık Bakanlığı tarafından kamuoyuna ilan edilmiştir. Hazırlanan SDP'nin 8 ana başlık altında ilerlemeyi hedeflendirmişlerdir.

Ülkemizde sağlık hizmetleri konusunda dönüm noktası olarak düşünülen SDP ile; sağlık hizmetlerinin etkin, verimli ve adaletli olarak sunulması, sağlık hizmetlerinin finansmanın sağlanması ve sunulması belirlenmiştir. Uygulamaya konulan bu hizmet programının temel maddeleri ise; insan temelli, sürdürülebilirlik ve süreklilik anlayışı üzerine kurulmasıdır. Hazırlanan bu programla sağıı sistemi son 10 yıl içerisinde yeniden düzenlenmiş ve bu yolda uzun yollar kat edilmiştir. Yaşanan olumlu gelişmelerden hazırlanan sağlık politikaları, sağlık ihtiyaçlarına duyarlı politikaların ve stratejilerin öncelikle yeniden oluşması, ikincil mevzuatın oluşturulması, politik istek, destek ve kararlılığın sürmesi, politik ve ekonomik istikrarın devam ettirilmesi, sürekli iyileştirmelerin sağlanması ve sistemi tehdit edecek girişim ve uygulamalardan kaçınılması sağlık sisteminin sürdürülebilirliği açısından büyük önem arz etmektedir. SDP'nin 2003'de planlanması ve uygulanmasına ilişkin bir kaç maddeye bakacak olursak;

Koruyucu ve Temel Sağıık Hizmetleri: Aile hekimliğine 2005 yılında pilot uygulama ile Düzce'de başlanmış ve 2010 yılından sonra tüm ülkede uygulanmıştır. Bu sistemde 1000-4000 arası bireye odaklı rekabetli bir sistem olarak ortaya çıkmaktadır. Ayrıca aile hekimliğinin bulunduğu yerde toplum sağlığı merkezleri de kurulmuş, bu merkezler tanı ve tedavi hizmetleri ve rehabilite edici hizmet dışında sağlığı tek çatı altında vermektedirler.

Aile hekimliklerinde isteyen kişi özgürce istediği hekimi seçme şansı verilmiştir. Ancak hekime istemediği kişiyi tedavi etmeme hakkının tanınması; hekimin çocuk, kanser hastalarına ve bunun gibi kronik hastalara bakmama riski ortaya çıkmaktadır, bu da kişilerin tedavi olma mağduriyeti ortaya çıkmaktadır. Ayrıca kentte bulunanların istediği şekilde seçim yapmasına olanak sağlayan sistem aynı olanağı köyde bulunanlara sağlamıyor. Kırsal kesimde bulunanlar il yönetimi tarafından en yakın aile sağlığı merkezine yönlendirerek eşitlik ilkesine ters düşmektedir (Zafer,2006).

Koruyucu hizmetlerin sağlanmasında aile hekimliklerine bağlı bireyler şeklinde mi yoksa koruyucu/önleyici toplumsal bir olgu olup, buna göre mi bir değerlendirme yapılacak şeklindeki belirsizlik, toplumda bir yaraya dönüşmektedir. Ayrıca aile hekimlikleri topluma yarar sağlayan, toplumun ihtiyaçlarını karşılayan koruyucu ve tedavi edici olması ve bunun yanında sevk sistemini formaliteden çıkararak bir düzenleme ile kurulması gerekmektedir.

2019 yılında aile hekimliklerine başvuran kişi sayısında bir artışın olması olumlu bir gelişme olarak görülsede basamaklar arası sevk zincirinin halen daha zorunlu olmadığını ve sağlık dönüşümde amaçlanının uygulanmadığı görülmektedir.

Teşhis ve Tedavi Hizmetleri: Sağlıkta Dönüşüm Programı'nın hedeflerinden biri verimlilik, "Kaynakları uygun şekilde kullanarak maliyeti düşürüp aynı kaynakla daha fazla hizmetin sunulması" olarak tanımlanmaktadır. Programda insan kaynaklarının dağılımı, malzeme yönetimi, sağılı işletmeciliği ve koruyucu hekimlik uygulamalarının bu esas çerçevesinde değerlendirileceği vurgulanarak ülkemizin bütün sektörel kaynaklarının sistem içine aktarılması yoluyla verimliliğin artırılacağı belirtilmiştir.

Hastanelerin tek çatı altında toplanması ile sağlık hizmeti sunumunda rol alan tüm kaynakları halkın hizmetine seferber edilmesi hedef alınmıştır. Sağlık Bakanlığı tarafından SSK (Sosyal Sigortalar Kurumu) hastanelerini devralarak, sağlık sisteminde kırılmalara yol açan ikili yapıyı ortadan kaldırılmıştır. Böylece tüm hastane gruplarına tüm hasta gruplarının erişimine açılmıştır. Sağlık sistemine bu müdahale, birçok dezavantajlı grupların sağlığa erişimini kolaylaştırmıştır. Yıllarca farklı sosyal güvenlik sistemleri içinde bulunan SSK'II, BAĞ-KUR'lu, devlet memuru, emekli ya da yeşil kartlı grupların hastanelerin tek çatı altında birleştirilmesi ile tüm hastane yapılarına erişiminin önü açılmıştır.

Tüm hasta gruplarının kamu hastanelerine erişimin önü açılmakla birlikte, birleştirilen sosyal güvenlik yapıları, SGK (Sosyal Güvenlik Kurumu) adı altında birçok özel hastane ile anlaşmalar yaparak, hasta gruplarının sosyal güvenlik kapsamında özel hastanelerden de hizmet alımının önü açılmıştır. SGK'nın anlaşmalı olduğu özel hastanelere teknik olarak erişmek mümkün olmasına rağmen, pratikte ek ücretler ödeneceği için gelir düzeyi düşük olan kesimler tarafından yeterince kullanılamamaktadır.

Hastanelere yetki devri, yönetim esnekliği, kendi kaynaklarını kullanma yetkisi verilmesi ve bunlarla birlikte çalışanlara döner sermayeden performansa göre ek ödeme yapılarak verimliliğin arttırılması düşünülmüştür. Bu durum sağlık profesyonellerinin aynı zaman diliminde daha fazla hastaya hizmet vermesi ve bir hastaya ayrılan sürenin azalması sonucunu ortaya çıkmıştır. Hastalara ayrılan zamanının azalması hasta memnuniyetini de negatif yönde etkilemektedir.

Sağlık Bakanlığı, yataklı sağlık kurumlarının amaçlarının yeniden belirleme çalışmasının önünü açmıştır. Hastaneleri bina, fiziki koşullar, donanım ve tıbbi teknolojik ihtiyaçlar, sağlık insan gücü kriterlerine göre planlayan bakanlık, kaynakların dengeli olarak dağılımını sağlamak amacıyla, sağlık hizmet sunumunda bölge sağlık planlaması anlayışını benimsemiştir. Buna göre, ülke genelinde bölge sağlık merkezleri ve her bir bölge için bölge sağlık merkezi konumunu üstlenecek merkez iller ve bu illere bağlı, alt bölge merkezi verilmiş iller belirlenmiştir (Hilmi,2009). 
Hastaların hakları konusunda; usulsuzluk yapılmadığı, bilgilendirmenin eksiksiz ve tüm aşamalarda yapıldığı ve kabulün alındığı, ayırım yapılmaksızın her türlü hizmeti aldığı, hekimini ve kurumunu seçebildiği, mahremiyete hassasiyetle uyulan bir hizmet anlayışı hedeflenmiştir. Hasta hakları konusunda bir diğer gelişme ise, hastanın hekimini seçme hakkı uygulaması olmuştur.

SDP'nin çalışanlara olan etkilerinden biri de Sağlık Çalışanını Koruma Programı'dır. Bu program ile “Çalışan Sağlığı ve Güvenliği Eylem Planı" geliştirilmiştir. MHRS (Merkezi Hekim Randevu Sistemi), vatandaşların hastanelerimiz ile Ağız ve Diş Sağlığı Merkezlerimiz için 182 Çağrı Merkezi'ni arayarak operatörlerden, istedikleri hastane ve doktor için randevu aldıkları bir hizmettir ve halen daha kullanılmaktadır.

SD (Sağlık Dönüşüm) sonrası, acil servisler ile ilgili yeni standartlar belirlenmiştir. Hastane yapısına göre bulunması gereken acil servis seviyesi belirlenmiştir. Acil servis seviyeleri; asgari personel, hizmet verilecek gruplar, fiziki olarak bulunması gereken malzemeler, erişim şartları ve tıbbi teknolojileri kapsamaktadır. Evde sağıı bakımı hizmetleri ile yatağa bağlı hastalarımızın yaşadıkları ev ortamlarında kaliteli, etkin, erişilebilir ve güvenli sağlık hizmeti almasının önü açılmıştır.

Kurumsal Yapılanma ve Kapasite Geliştirme: Sağlık çalışanlarının ülke genelinde dengeli dağılımının olmaması eski dönemin de en önemli problemlerinden biri olduğu görülmüştür. SDP’nin önceliklerinden biri de bölgeler arası sağılk çalışanlarının dağılımında dengeli bir düzeye çekilmesi, personel istihdamında unvanlara göre gerçekçi standartlar belirlenerek buna göre insan gücü planlamasının yapılması, atama ve nakillerde gerçekler göz önüne alarak ve hakkaniyete uygun bir sistemin kurulması olmuştur.

Gelişmiş ülkelerin çoğunda sağlık sistemleri, kalite standartları ve eşitlik maddeleri çerçevesinde bütün nüfusu kapsayacak şekilde yapılandırılmıştır. Yaklaşımlar, değişiklik gösterse de sağlık hizmetlerinin finansman ve organizasyon sorumluluğu merkezi ve bölgesel otoriteler arasında dağılım yapılmıştır. Ancak genellikle devlet esas belirleyici konumda olmuştur.

SDP'den önce Türkiye'de kamu hastanelerinde çalışıp da özel muayenehanesi olan çok fazla uzman hekim vardı. Halk, önemli hastalıklarını takip ettirirken cebinden ek ödeme yapmadan kamuda çalışan doktorlara ulaşamıyordu. Bu durum ne yazık ki hekimlerin doğal hakkı, hastaların ise kaderi olarak kabul ediliyordu. Kişilerin özel muayenehanelere gitme ihtiyacını ortadan kaldırmak amacıyla sağlık personelinin "Tam Gün” çalışmasına yönelik bir kanun çıkarılmıştı. Bu kanun ile kamuda çalışan sağlık personelinin çalışma yönetmelikleri yeniden düzenleyerek hem vatandaşlarının sağlık hakkına kolay ve hakkaniyetli bir erişe bilirliği hem de sağlık personelinin mesleki saygınlığına kavuşması yönünde düzenlemeler getirilmiştir. (Resmî Gazete, 2018).

Tam Gün Uygulaması; Sayıca yetersiz olan sağlık çalışanlarının üzerindeki iş yükünü daha eşit bir hale getirmek, doktorlar ile hastaları arasında doğrudan maddi işbirliğini ortadan kaldırmayı, vatandaşlar ile hekimlerin arasındaki güven ilişkisini güçlendirmeyi, hastaların sağlık hizmetine erişebildiğini kolaylaştırmayı hedeflenmiştir.

Sağlık Bakanlığı, Tam Gün Yasası'nı esneterek yeni kanunlarla, bakanlık onayıyla devletten ya da özelden her hekim tek sözleşmeyle 'bir ameliyata' girebilecekti. Bakanlık, tüm doktorları bir alanda toplayarak, ihtiyaç dahilinde yarı zamanlı ameliyatla doktor başka bir hastaneye çağrılabilecekti. Böylelikle ne devlette ne de özelde 'doktor eksikliğinden' yapılamayacak tedavi olmayacaktı. Bu model devlet ve özelde çalışan tüm hekimleri kapsayacak şekilde bir model değişikliğine gidilmiştir.

Kamu Hastaneler Birliği: Kamu hastane birlikleri idari ve mali özerkliğe sahip sağlık işletmeleri olarak bilinir. Bu kurumda bütün sigorta kurumlarda ayırım olmaksızın hepsi e-sözleşme yapmak ve sevk sistemini esas almak, bütün vatandaşlarınıza hizmet vermektir. Kurumlar değil bireylerin öncelik verildiği bir sistem, fiyat uygulaması denetim atına alınarak, bunu sunan kurumlar ürettiği hizmet kadar finansal pay alacaktır. Bu kamu hastanelerinin değişen yapıları ile sektörün diğer kısmı ile rekabet edebilmesi için merkeze bağımlığı yapısından kurtularak yerel ve hızlı bir hizmetin sunumuna dönüştürerek özerk bir yapıya kavuşturmaktır. Her tesis kendi özerkliğine sahip olup devlete bağı olmak zorunda değil ve bu kurumlar kendilerini finanse etmek, hizmet kalitesini yükselterek pahalı kurumlar olmasına izin verilmeyecektir. Hizmetlerin sürekliliği ve kalitesine katkı sağlanarak, sağlık kuruluşlarının öncelikli amacı kâr amacı olmayan, yatırım ve planlama yapan, yerel dinamiklerin karar mekanizmasında rol aldı̆̆ı müşteri merkezli planlanan yapılardır.

2012 yılında sağlık kuruluşlarının yönetim yükünü hafifletmek, ihtiyaçlara hızlı cevap verebilmek açısından Kamu Hastane Birlikleri kurulmuş. Bu kurum hastanenin mali yükünü üstlenmek ve profesyonelce yürütmektir. Hastanenin sadece tetkik ve tedaviyi daha iyi şekilde yapması için kurulmuştur. İlk üç yılda olumlu gözükse de ondan sonra yönetimi işin ehli olanlar yönetmediği ve çok başlılık ortaya çıktığı ayrıca sağlık çalışanlarının görmezlikten gelindiği şekline dönüşerek başarısız olmuştur. 2017 yılında kanun hükmünde kararname ile kaldırılmıştır ve yeniden il sağlık müdürlüklerine bağlanmıştır (Sedat ve Gökhan,2019).

Şehir Hastaneleri: Devlet mekanizması, etkin ve verimli bir şeklide, fiyat merkezli, bürokratik olmayan, piyasa ve müşteri ilişkisi odaklı olarak yeniden kurgulanmıştır. Tüm dünyada etkili olan neo-liberal politikalar Turgut Özal zamanında başlayıp, son zamanlarda etkisi daha fazla olduğu hissedilmiştir (Mustafa vd., 2004). 
Bundan dolayı kamu hizmetlerinin yerine getirilmesi ve yürütülmesi devlet, özel sektör ve sivil topum kuruluşlarını bir araya getiren fayda ve maliyet analizini, rizikoyu tüm aktörler tarafından paylaşılan KÖO (Kamu Özel Ortaklığı) yönetimi ortaya çıkmıştır (Durmuş vd., 2018). Bu bağlamda KÖO kapsamı ile ilgili şehir hastanelerinin SDP kapsamı içerinde gerçekleştirmektir.

Dünyada artan reform hareketleri ve artan yaşlı nüfusu oranı ve sağlık teknolojilerinin kamu maliyesi üzerinde artması belirli reformları yapmak zorunda bırakılmaktadır. Bundan dolayı kamunun sunduğu sağıık hizmetlerini piyasa aktörleri ve bireyleri ile paylaşmayı sağlamaktır. Sağlık hizmet temelini yeniden yapılandırması piyasa temeli olması IMF (Uluslararası Para Fonu) ve Dünya Bankası gibi kuruluşlar tarafından desteklenmektedir (Davuthan,2011). Dünyada gelişen birçok hastalık ve bunlarla mücadele etmek oldukça zorlaşan ve maliyeti yüksek olan durumlardır. Türkiye'de KÖO modeli kapsamında şehir hastaneleri kampüsü hayata geçirmektedir. Bu da SDP üçüncü ayağı olarak gerçekleştirmektir (Durmuş vd.,2018).

\section{Şekil 1: Sağlık Sektöründe İşbirliği Kapsamında Kamu/Özel Sektör Ortaklıklarının Başlıca Türleri}

\begin{tabular}{|l|l|}
\hline \multicolumn{1}{|l|}{ Sözleşme Kapsamı } \\
- Hizmet Sözleşmeleri \\
- Yönetim Sözleşmeleri \\
- İnşaat, Bakım ve \\
Ekipman Sözleşmeleri \\
- Karma Sözleşmeler \\
- Kiralama
\end{tabular}

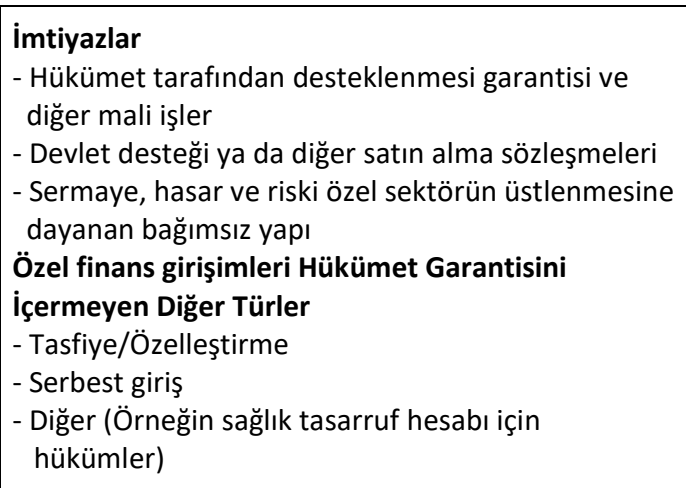

Yukarıdaki tabloda KÖO ortaklığının başlıca türlerini görülmektedir. KÖO’de çeşitli modeller vardır. Ancak bakanlığının tercih ettiği model, yap-kirala-devret modelidir. Sağlık Bakanlığı yapılan şehir hastanelerini bu model ile hayata geçirmektedir. Kamu Özel Ortaklığı ile ilgili proje Sağlık Bakanlığı'nın pek çok ilde gerçekleştirmeye başladığı şehir hastaneleridir. Bu projelerinin temel mantığı; projenin finansmanı, fiziksel ekipman, bakım, onarım ve yenileme işlerinin özel sektör; sağlık hizmeti sunma ve proje alanındaki müşteri garantisinin ise devlet tarafından verilmesi üzerinden işlemektedir. KÖo kapsamında belirlenen şehirlerde kurulan şehir hastaneleri yapımına özel sektörün katılımı sadece hastanelerin inşaatı ile sınırlı olmayıp, hekimlik hizmeti dışındaki otopark, kafeterya gibi birtakım alanların ticari işletme hakkını da kapsamaktadır. Bunlar Sağlık Bakanlığı bünyesinde olacaktır (Ferimah ve Derya,2011). Kamu Özel Ortaklığı modeli ile bu tesisleri kiralama karşılığı yaptırılması tıbbi hizmet veren alanların dışındaki alanları işletme gayesi ile yapılması amaçlanmıştır (Ertuğrul ve Sabiha, 2012). Devletin sadece tıbbi hizmet alanında var olduğu onun dışındaki tıbbi destek üretiminde ve tıbbi olmayan hizmetlerin işletilmesini özel olan ortağına devretmesidir (Koray,2011).

Sağlıkta Finansal Yönetim: Türkiye'de de sağlık hizmetlerinin finansmanının bir ayağında yer alan Sosyal Güvenlik Kurumu'nun temel gelirini oluşturan primler 1980'den sonra yeterli olmamaya başlamış ve sonrasında da açık vermeye devam etmiştir. Bu duruma bir çözüm olarak hazineden, genel vergi gelirlerinden transferler yapılmaya başlanmıştır. Bu transferler, aslında SGK primlerinin karşılaması gereken sağıı harcamalarına yatırıldığı için kamusal yatırımlar ve harcamalardan kısılmıştır. SGK'ya prim ödemesini zamanında ve doğru bir şekilde yapan ve aynı zamanda devlete vergisini ödeyen bir 279 vatandaştan da aynı hizmet konusu üzerinden iki kere para alınmış, sonucunda vatandaş çifte vergilemeye benzer bir duruma maruz kalmıştır. Tanımı gereği karşıııksız olarak alınan genel vergilerin, finansmanı için sosyal parafiskal gelirlerin toplandığı sağlık hizmetine aktarılmaması gerekmektedir. Bu durum maliye kavramları arasında karışıklık oluşturmaktadır. SGK'nın açık vermemesi, ekstra transfer ihtiyacını durdurabilecek tek noktadır. SGK denetimlerinin artırılması gerekmekte ve kayıtsız işçi çalıştırılması önlenmeli, sigortalanan her çalışanın prim ödemeleri kontrol edilmelidir. Sonuç olarak; SGK'nın prim gelirlerinin sağlandığı taban genişletilmeli ve SGK gelirlerinin artırılabileceği yöntemler aranmalıdır (Aktel vd., 2013).

Bir sağıı sisteminin en temel amaçlarından biri toplumun sağlık ihtiyaçlarını, finansal risklerini korumaya yönelik ilkelerini gözeterek herkese eşit ve kabul edilebilir bir kalitede hizmet sunmaktır. Bu nedenle hizmet kullanımının ve sağık harcamalarının artması ile baskı altına alınması gereken konulardır. Ancak her iki konudaki artış gereksiz kullanım ve kaynakların verimsiz kullanımı nedeni ile ortaya çıkıyorsa bu durumda da geri ödeme kurumu toplumsal fayda için gereken önlemleri de almak durumundadır. Türkiye'de sosyal sağlık sigortasının sürdürülebilirliği ve geleceği açısından bu ve ilgili konuları irdeleyecek ve sağlık politikacılarına yön vererek, gerçekçi politika belirlemelerine yardımcı olacak çalışmaların yapılması gerekmektedir. 


\section{INGILTERE SAĞLIK HIZMETLERI POLITIKALARI}

\subsection{0-2010 Arası Sağlık Politikaları}

Ingiltere'de NHS (Ulusal Sağlık Sistemi) ortaya çıkmadan çok önce sağlıkçılar toplum içinde kendilerini göstermeye başlamıştır. Çoğunlukla berberden dönüşerek ortaya çıkan bu sağlık hizmetinin verilmesi o günün hekimleri olarak kabul gördü ve o dönemdeki önemli bir sağlık hizmet açığını tamamlamıştır. Oluşan hizmet "aile hekimi” modeliydi ve Avrupa'da en çok gelişerek örgütlendiği yerlerden biri de İngiltere idi. Bu dönemde bu örgütlenmeye katkı sağlayanlar arasında; Kilise ve din okullarındaki Rahibeler sağlık hizmet bakımı üstlenmişlerdir. Kurumları giderek hastane yapısına dönüşerek rahibeler de yavaş yavaş hemşire unvanını almaya başlamışdır. Ortaya çıkan bu birliktelik toplumsal bir gelişme olup sağlık algısının oluşması sürecinde duyulan ihtiyaçları karşılamaya yönelmişlerdir.

Hastanelerin çoğu ücretli olup, bu nedenden dolayı yoksulların çok küçük bir kısmı bu hizmetlerden yararlanırken ödeneklerden faydalanıyorlardı. 19. yüzyılında yardımsever ve reformcular, yoksullara ücretsiz olarak sağıı hizmeti sağlamayı denemişlerdir. 1844 yılında, şimdilerde; Kraliyet Serbert Hastanesi olarak bilinen bir dispanser kurulmuştur.

Dispanser, zor süreçlere girdikten sonra hizmet karşılığı ödeyebilenden, ödeyebildiği ücreti istemeye başladıktan sonra 1920'de iflas noktasına gelmiştir. Aynı dönemde yerel yönetimler de hastaneler kurmaya başlamıştır. Büyük değişim Birleşik Krallık sanayi devrimi ile başlamıştır. Hızlı kentleşme ile ağır çalışma şartları insanlık dışı yaşam ve sağlıksızlık koşullarını da beraberinde getirmiştir. Sanayi bölgeleri en yoksul alanlardı ve oralar da ölüm hızlarının en yoğun olduğu yerlerdi (Engels,1987).

Kraliçe'nin adıyla anılan "Viktorya Britanyası" sürecinde içeriği çok daha sonra anlaşılan beklenmedik bir gelişme oldu; Yetişkin ölümleri hızla azalmaya başlamıştı. İlerleyen yıllarda bunun nedeni gelirin artışına bağlı olarak beslenmenin düzeltilmesi yönünde yapılmıştı. Daha sonraki incelemelerden erişkin ölümlerinin hızla azalmaya başlamasının artan geliri kamu sağlık hizmetlerine harcamaya başlayan yerel yönetimlerin katkısıyla olduğu ileri sürülmüştür (Szreter,1997).

1930'lu yıllarda Sağlık Bakanlığının girişimiyle Sovyetler Birliği'nde ve diğer Doğu Avrupa ülkelerinde biçimlenen sağlık hizmetleri modelleri incelenmeye başlanmış ve yeni sağlık sistemleri hazırlanmıştır. Mevcut sağlık sigortası sisteminin ücretlilere bakmakla yükümlü olduğu kişileri de kapsayacak şekilde genişletilmesi ve gönüllü hastanelerin tümleşik edilmesi konusunda giderek artan bir fikir birliği vardı. 1939 'da İkinci Dünya Savaşı'nın başlaması nedeniyle daha fazla önem verilmemiş; Savaş zamanı, yaralılara bakmak için Acil Hastane Hizmetinin oluşturulması gerekmiş ve bu hizmetleri hükümete bağlı kılınmıştır. İngiltere'de sağlık hizmetleri konusu giderek büyüyen bir sorun oluşturmuştur.

1941'e kadar Sağlık Bakanlığı, hizmetlerin kamuya açık olması amacıyla savaş sonrası sağlık politikasını kabul etme sürecinde olup, bir yıl sonra Beveridge Raporu "kapsamlı sağlık ve rehabilitasyon hizmetleri" için bir öneri getirmiş ve Avam Kamarası genelinde tüm taraflarca desteklenmiştir. Sonunda, Bakanlar Kurulu 1944 yılında Sağlık Bakanı Henry Willink'in NHS yönergelerini belirten ilkeleri onaylamıştır. İlkeler, ulusal sigortadan değil genel vergilendirmeden nasıl finanse edileceğini içeriyordu. Ülkeyi ziyaret edenler de dahil olmak üzere herkes tedavi görme hakkına sahipti ve teslimat noktasında ücretsiz olarak sağlanacaktı. Bu fikirler bir sonraki Sağlık Bakanı Aneurin Bevan tarafından alınmıştır (Szreter,1997).

1945 yılında Clement Attlee iktidara geldiğinde ve Aneurin Bevan Sağlık Bakanı olduğunda projenin temel taşları yerine oturmaya başlamış. NHS'yi şimdi bildiğimiz biçime getirmek için kampanyaya başlayan Aneurin Bevan'dı. Bu projenin Bevan'ın 5 Temmuz 1948 'de dile getirdiği üç fikre dayandığı söyleniyordu. Bu temel değerlerin birinci, hizmetlerin herkese yardımcı olduğu; ikincisi, sağlık hizmetlerinin ücretsiz oluşu ve son olarak ödeme, ödeme kabiliyetinden ziyade ihtiyaca göre sağlanmasıydı.

NHS kanunu 1946'da kabul edilerek 1 Temmuz 1948 yılında yürürlüğe girmiştir. 1948'de NHS'nin yaratılması, yıllarca süren sıkı çalışmanın ve mevcut sağlık sisteminin yetersiz olduğunu ve devrim yapılması gerektiğini düşünen çeşitli figürlerin motivasyonunun ürünüdür.

NHS'nin ilk yıllarında kısa bir süre sonra, harcama zaten önceki beklentileri aşmış ve reçetelerin artan maliyetleri karşılaması için ücretler düşünülmüştür. 1960'lara gelindiğinde bu erken düzenlemeler değişmiş ve ilaçların mevcudiyetindeki yeni gelişmeler ile karakterize edilen NHS için güçlü bir büyüme dönemi olarak kabul edilmiştir.

Yıllar geçtikçe yeni değişiklikler yapılmış ve 1974 'te, daha önceki on yılı karakterize eden ekonomik iyimserlik dönemi azalmaya başladığı için yeniden yapılanma meydana gelmiş. 1980'lerde ve Thatcher hükümetinde modern yönetim yöntemleri uygulamaya konulmuş. Bununla birlikte, refah ve kamu konutları gibi diğer alanlardaki fikirlerin çatışmasına rağmen, NHS'nin İngiliz halkı için kritik bir dayanak noktası hizmeti olarak kalmasının gerekliliği yine de Margaret Thatcher tarafından önceliklendirilmiştir. 
Beveridge modeli genel tanımı ile hasta olanlara öncelik tanınarak sağlık hizmetlerinin oluşturulması, gerekli ailelere yardım imkânı sağlaması, işsizlik sigortası, dullara aylık bağlanması, doğum ve ölüm durumunda ödenme yapılması gibi öneriler içeren 1942 yılında William Beveridge tarafından sunulmuş bir model olarak bilinmektedir.

$\mathrm{Bu}$ dönemde ekonomik problemler ve yönetsel yapının oluşturulmasında zorluklarla karşılaşılmıştır. Asslında bu sağlık uygulamasının öncesinde önemli ve çok sert tartışmalar yaşanmıştır. Bu farklı modeller ve bağımsız çalışmaya alışkın meslek ve meslek kurumlarını bir araya toplayarak yeni bir sürece alıştırmaya çabalıyordu. Farklı dallarda ilı sağlık çalışanları bu model ile birlikte ortak hizmet üretmeye çabalayacaklardı. Sağlık ocağı veya diğer adıyla aile hekimliklerini bütün sağlık personeli ile beraber sunacakları emekli aylıklarının yükseltilmesi hizmet birimi olarak hazırlanmış. Ancak; doktorların farklı görüşleri sebebiyle başlatılamamış. Hizmeti sunan birimlerinin kamu hastaneleri ve sağlık ocakları oluşacağı ve aile hekimlerinin gerektiğinde hastaları hastanelere sevk edeceği, aile hekimliklerini birincil koruyucu sağlık hizmet sunacağı bir sisteme evrileceği işin başından belliydi (Gazanfer ve Hatice,2006).

Hizmet planlamanın başlangıcında toplum içinde bilinmeyen bir genişlikte hastalık çoğunluğundan söz ediliyordu. Hastalık çoğunluğunun bu sistemin vermiş olduğu sağlık hizmetine oranla azalacağı, zamanla hizmetten yararlananların sayısı belirli bir seviyede kalacak veya azacaktı. Fakat hesaplanan bu sistem ile gelişmeler istenilen oranda olmadı, yıllar geçtikçe hasta sayısı ve maliyetler hızla artmaya başladı. Aynı zamanda kurumlar arası farklılıklar meydana gelmeye başladı. Hastaneler, aile hekimleri ve yerel sağlık yetkilileri birbirinden ayrı hizmet veriyorlardı (Ham,2005).

1970'lerde sağlık yönetiminde "kurumsal" bakış açısı yaygın hale gelmiş ve kişi temelli bir finansman sistemi sürdürülmüştür. Fakat yönetim ile çalışan arasındaki bağlar, bazı güçlü olan sendikalar tarafından daha da kötüleşmiştir (Ham,2005). Kötü hizmet koordinasyonunun üstesinden gelmek için NHS'nin yeniden düzenlenmesi 1974'de uzun bir araştırma ve danışma 1970'lerin başında iktidarda olan Muhafazakâr Hükümetin 1974'te devralınan hükümet tekliflerle devam edilmiş.

Sağlık hizmetleri 1974 yılına kadar yerel yönetim tarafından yürütülmüş, 1974'ten sonra özel sağlık kuruluşlarına aktarılmıştır. Muhafazakâr hükümet, 1980 ve 1988 yılında iki ayrı yasa ile merkezi yönetim düzeyindeki hizmetlerde açık ihale sistemi devreye girmiştir. 1986 yılına kadar tüm sağlık hizmetlerinin \%68'i ihaleye açılmış ve \%20’si özel sektör tarafından yürütülmeye başlamıştır. (Ham,2005).

Margaret Thatcher'ın 1979 yılında yönetime gelmesiyle birlikte NHS, piyasa tarafından zor zamanlara girmiştir. Thatcher başa geçtiğinde Washington çerçevesinde özelleştirme pazarını geliştirmek için ABD başkanı Ronald Reagan ile iletişime geçmiş. Görev süresinin bitimine yakın sağlık hizmetlerine önem vermiş, ABD'li ekonomist Alan Enthoven'ı getirerek (1985), onun öne sürmüş olduğu "iç pazar" kavramını sağlık hizmetinde rekabetinin arttırılması gerekliliğini vurgulamıştır. Başlarda NHS'nin ana yapısında değişiklik yapmadan piyasa güçlerini sistem içine dahil edilmek istese de bazıları Thatcher'ın temel amacının sağlık hizmetlerinin özelleştirmeye dayalı olduğunu söyleyenlerde olmuştur (Mooney,2012).

Thatcher'ın o dönemdeki politikaları, sosyal, ekonomik ile sağlık adaletsizliğe bağlanmış, bu konulara önem vermeği söylenmiş. Thatcher yönetim döneminde, sistemi yeniden güncellenmiş. 1990 yılında hastane bakımından sorumlu, bağımsız tröstler kuran Ulusal Sağ ık Sistemi ve Toplum Bakımı Yasası devreye girmiş. Hastaneler Sağlık Bakanlığı'ndan direk olarak bağlı NHS tröstleri olarak planlanmıştır. Vakıf tröstleri kendini idare eden ve yarı idari devlet tröstleri olarak kurulmuş.

Toplum Bakımı Yasası'ndan önce NHS sistemi eş merkezli yapısal yasal işlemler ile yürütülmüştür, ancak iç pazarın yenilenmesiyle sağlık hizmeti verenlerle, hizmeti alanlar için aile hekimleri ve sağlık otoritelerine bütçe verilmeye başlanmış. İç piyasadaki sağlık kurumları ise tamamen tröstlere dönüşmüş. Özelleştirmesi arttırmış artık Sağıık Bakanlığı'na ait olmayıp, yeni bir sağlık piyasası birimine bağlanacak. Bu vakıflar, ticari konular barındıran yollarla veya özel firmalarla ortak ticaret kurarak maddi bir gelir elde edilmiş. Bunun sonunda NHS'ye bağlı kurumlar özel işletmelere dönüştürülmüş (Hermann,2010).

Ingiltere'deki sağlık hizmetlerinin işleyişi önemli değişiklikler gerçekleşmiş. NHS'nin düzenlemeleri 1991 başlarında öne çıkmış, en önemli değişimi iç pazar anlayışı olmuştur. 1996 - 1997 arası yıllarda reformlar bir kısmı uygulansa da devlet değişikliklerinin de eklenmesiyle beraber düzenlemeler tam etkisini görememiştir.

Hizmet sunumunda uygulama kısmında yüksek maliyetler istenildiğinden dolayı hizmette istenilen performans gözlenmemiştir. NHS sistemin temel amacı verilen hizmetin kalitesini artırmak olsa da hizmet seviyesi aşağıda kalmıştır. Sağlık yönetimi ulusal düzeyde bir eğitim ve uygun sağlık hizmetleri uygulaması geliştirerek bu konuda öncülük etmiştir (Jakubowski ve Busse,1998).

Bu durum sağlık sisteminin gittikçe; maliyet artırımına, sistemin parçalanmasına, özelleştirilmesine vb. sorunlara neden olmuştur. Bu sorunlara daha fazla yol açmamak için çeşitli önemler almaya başlamıştır. 
Bu nedenle ilk işletim yeri olarak NHS üstlenmiştir. 2002 hükümet döneminde sistem kâr amacı güden bir sistem olarak sürdürülmüştür. Bu sistemle birlikte rekabet gücü olan maliyet sunabilecek ve bu sebepten dolayı NHS daha ucuz bir maliyet sağlayabilecekti (Hermann,2010).

\subsection{Yılı Sonrası Sağlık Politikaları}

Liberal Demokratlar ve Muhafazakârlar birleşmesi ile 2010'da iktidara gelmesiyle yeni bir sistem devreye girmişti. Bu dönem için sağlık hizmetleri için kökten bir değişiklik olmayacağı dile getirilmiş fakat durum tamamen olmasa da yeniden bir değişikliğe girilmiş. Yeni düzenlenen İngiltere'nin sağlık sistemi, hizmetin neredeyse tüm düzeyini yeniden ve tepeden tırnağa radikal değişimlere uğramıştır (Peckham,2014).

Nisan 2013 öncesinde, birinci basamak hizmetleri NHS bütçesinin çoğunluğundan yükümlüdür. Belli birçok alan için birinci ve ikinci basamak sağlık hizmetlerinin genelini vermekle yükümlülerdir. 2013 Nisan ayından itibaren ise, bütün sağlık piyasasında hiçbir kurumun ve aile hekimliğinin bütçesinin olmadığı belirtilmiştir. 2010 yılında sunulan ve 2012-2013 yılları arasında yürürlüğe giren NHS'sindeki değişiklikleri (Peckham,2014); maddi güç için çoğulcu bir model oluşturmaktır, daha çok özelleşmeye alan yaratmak, ancak seçici bir zeminde, merkezi olarak belirlenen unsurlara göre performansa bağlı değerlendirmesinde kalmak ve klinisyenler tarafından yürütülen, örgütsel düzeni destekleyen, kendi kendine devam eden bir teşvik edici bir sistem gelişirmek, halinde açıklamaktadır.

David Cameron'un 2010'da yönetimi devir almasıyla birlikte NHS yeniden organizeli çalışmaya başlamıştır. Cameron, "NHS'deki açıkları kapatmaya değil maliyetlerdeki açıkları kapatmaya" dair söz vermiştir. Ancak koalisyon politikaları, sağlık üzerinde de aşağıda belirtilen şekillerde de etki yaratmamıştır (Vizard ve Obolenskaya,2015):

Bu dönemde sağlık harcamalarını diğer harcamalara göre koruyacağını belirtirken, gerçek sağlık harcamalarındaki genişleme önceki hükümet koşullarına göre aşağıda görülmektedir. Yıllık olarak büyüme rakamlarına bakıldığından, artan ihtiyaç ile talebe karşılık olarak, NHS sağlık hizmetlerini sürdürmek ve genişlemek için gerekli olan rakamların oldukça altında kaldığı görülmektedir. Bu durumla ilgili olarak İngiltere sağlık açısından olan yönetim politikasının alanının genişletmiş ve değiştirmiştir. Bu süreçte NHS, Vakfı Vakfı Tröst Halk Soruşturması ile birlikte, en az bakım şartlarını, hizmetleri ile kalite açısından tekrar düzeltmeye ve güçlenmeye gidilmiştir. Halkın NHS'den memnuniyet oranı istenilen düzeye ulaşılamamıştır. OECD verilerinde 2007 yılında ekonomik krizle beraber ruhsal sorunlar ve intihar sayıları artmıştır. Bu dönemde sağlık eşitsizliği artmış ve çevre koşulların iyi veya kötü olmasına göre ortalama yaşam beklenti oranı erkekler ve kadınlar arasındaki oranı da etkilemiştir. Bu nedenlerle sağlık açısından iyileştirmeye ve eşitsizliği aza indirmeye önem verilmiştir (Uysal vd., 2012). Birçok göstergelerde performans yüksekliği artsa da 2010'dan günümüze sağlık hizmetlerde bekleme süreleri yavaşlatılmıştır (Bevan vd., 2014).

Son dönemlerdeki İngiltere sağlık politikalarındaki varyasyonlar, Theresa May hükümeti ile bir kademeye geçmiştir. Çünkü May, 23 Haziran 2016'da yapılan referandumdan yüksek oy sonucu ile AB'den ayrılma (Brexit) sürecini girmiştir. Brexit sonrasında kamuoyunun hemen her kısmı tarafından konuşan ve tartışılan konu Brexit'in İngiltere'nin sağlık hizmeti yani NHS için sonuçların kötüye gideceği görüşündedir. İngiltere'nin $A B^{\prime}$ den ayrılışı sağlık hizmetleri finansmanını, sağlık işgücünü ve vatandaşlarının Avrupa ülkelerindeki ziyareti sırasındaki sağlık hizmetlerine erişimi konularında ciddi sorunlar ortaya çıkacaktır. Sistem vergilerle karşılandığı için ekonomideki değişiklikleri doğrudan etkilemektedir. Ingiltere için genel olarak kamu hizmeti acısından daha az kaynak kullanımı olarak algılanmaktadır. Ve bunun yanında İngiltere'de yaşan AB vatandaşlarında bu durumdan etkilenerek kendi ülkelerine geri dönüşlere başlamıştır. Bunun yanında bir de Avrupa vatandaşaları Avrupa ülkelerinde ücretsiz bir sağlık hizmetleri alırken İngiltere $A B^{\prime}$ den ayrıldığından dolayı bu hakkı da reddetmiş oluyor. Bu sistemde diğer sistemlerde olduğu gibi finansal bir sürdürülebilirlik, sağlık hizmetlerinde kalite, verimlilik ve erişebilirlik gereklidir. Bundan dolayı bu konular açısından ciddi bir sorun ve endişe duyulmaktadır. Ayırlması sağlık hizmetinin yavaşlamasına ve ilaç tedarik konusunda sıkıntılar başlamıştır.

İngiltere'nin AB birliği tarafından gelen ziyaretçileri için devlet tarafından sunulan (EHIC) sağlık hizmetlerine ulaşımı ve S1 planı ile Avrupa'da yaşayan vatandaşların sağlık hizmetlerine erişimi bu ayrılık dönemimde devam ediyor. 31 Ocak 2020'de İngiltere tamamen $A B^{\prime}$ den ayrılmıştır. AB ile İngiltere'nin diğer yıllardaki ilişkilerinin durumumun netleştirmesi için bir geçiş dönemi olacaktır. Brexit'in sağlık alanındaki etkilerini zamanla fark edilecektir.

\section{INGILTERE ILE TÜRKIYE'NIN SAĞLIK POLITIKALARININ KARŞILAŞTIRMASI}

Türkiye sağlık sisteminin finansal kaynakları, işçi ve işveren tarafından karşılanan primlere dayanmaktadır. Primler işçilerin gelirlerinin belirli bir oranı denk gelmektedir. Aynı şekilde işveren katkı payları da iş̧̧inin gelirinin belirli bir oranından oluşmaktadır. Alınacak primlerin alt ve üst sınırları bulunmaktadır. İşçi ve işverenden toplanan primlerin yetersiz kaldığı durumlarda ise sağlığın finansmanı genel bütçe tarafından sağlanmaktadır. İngiltere'de ise sağlık sisteminin finansal kaynağı vergilerdir. 
Sağlık hizmet sunumu ve finansmanı açısından birbirlerinden oldukça farklı özelliklere sahiptir. NHS ve GSS sistemlerinin ortak özellikleri; ilk olarak hem GSS'de hem de NHS'de verilen sağlık hizmetleri tüm nüfusu kapsamakta ve kişiler doğrudan sağlık hizmetinin içinde söz ve hak sahibidirler. Türkiye'de GSS tüm vatandaşlara kapsamlı bir sağlık hizmet sunmakta ve bunu zorunlu olarak yapmaktadır. Benzer şekilde NHS'de toplumun tüm kişilere verimli ve kolay erişilebilir sağlık hizmetini sunmakta görevlidir. "Ulusal Sağıık Hizmetleri tüm halka aittir" anlayışı çerçevesinde hizmet gösteren NHS, tüm nüfusa yönelik mali yükümlülük olmadan sağlık hizmetleri ve tıbbi bakım sağlık hizmeti sunmaktadır. İki uygulama arasındaki bir diğer ortak özellik ise sağlık hizmetlerinde kamunun ve kamu finansmanının katkısının fazla olmasıdır. İki uygulama arasındaki en önemli farklılık; Ülkemizde karma bir sağlık finansman uygulanırken, İngiltere'de standart Beveridge sağlık finansmanı uygulamasıdır. İngiltere'de sağlık hizmetlerine ayrılan finansman kısmını çoğunlukla vergilerle karşılanmaktadır. GSS ise işçi ve işverenlerin ödedikleri primlerle sağlık finansmanı karşılanmaktadır. Bu iki uygulama arasındaki hizmet sunumu olarak farklarına bakıldığında ise en önemli fark, sağlık hizmet basamakları arasında zorunlu ve serbest sevk zincirinin uygulanıyor olmasıdır.

Çünkü Türkiye'de zorunlu bir sevk zinciri uygulanmazken, İngiltere'de bu durum zorunlu bir sistem uygulanmaktadır. Birinci basamağa yapılan başvurularda katkı payı alınmazken, ikinci veya üçüncü basamak sağlık kuruluşlarına yapılan başvurularda katkı payları alınmaktadır. Özel hastanelere yapılan başvurularda ise katkı payları ile beraber ek ücretler alınmaktadır (Abdulaziz,2017).

Tablo 3: İngiltere ve Türkiye'nin Bazı Sağlık Göstergeleri

\begin{tabular}{|c|c|c|}
\hline Göstergeler & Türkiye & İngiltere \\
\hline Toplam Nüfus (2020) & $83,614,362$ & $66,796,807$ \\
\hline Kişi Başına GSYH (ABD Doları) (2019) & 9,043 & 42,300 \\
\hline 0-14 Yaş Nüfus Oranı \% (2019) & 23,1 & 18,6 \\
\hline 60/65 Yaş Arası Nüfus Oranı \% (2019) & 9,1 & 18,31 \\
\hline Kişi Başı Hekime Müracat Eden Sayısı (2019) & 9,8 & 4 \\
\hline 10.000 Kişiye Düşen Yatak Sayısı (2019) & 28,6 & 25,0 \\
\hline Kaba Doğum Hızı (2019) & 14,4 & 11,5 \\
\hline Kaba Ölüm Hızı (2019) & 5,3 & 9,4 \\
\hline Hastanede Ortalama Kalış Süresi (2019) & 4,2 & 6,8 \\
\hline Toplam Doğurganlık Hızı (2019) & 1,9 & 1,7 \\
\hline Bebek Ölüm Hızı (2019) & 9 & 3,8 \\
\hline Beş Yaş Altı Ölüm Hızı (2019) & 13 & 4 \\
\hline Doğumdan Beklenen Yaşam Süresi (2019) & 77,31 & 81,15 \\
\hline 1000 Kişiye Düşen Toplam Hekim Sayısı (2019) & 193 & 284 \\
\hline Toplam Kişi Başı Sağlık Harcaması (ABD Doları) (2019) & 1,235 & 4,290 \\
\hline AIDS İnsidansı (2019), (100.000 Nüfusta) & 0,1 & 0,4 \\
\hline Sitma İnsidansı (2019), (100.000 Nüfusta) & 0,3 & 2,6 \\
\hline Yataklı Tedavi Kurumlarında 1.000.000 Kişiye Düşen MR Cihazı Sayısı (2019) & 10,8 & 7,2 \\
\hline Yataklı Tedavi Kurumlarında 1000 Kişiye Düşen BT Cihazı Sayısı (2019) & 14,6 & 9,5 \\
\hline 1.000 Kişiye Düşen Günlük Antibiyotik Tüketim Miktarı (2019) & 31,9 & 18,0 \\
\hline
\end{tabular}

Tabloda, Türkiye ve İngiltere'nin; WHO, OECD, TUik ve Türkiye Sağlık Bakanlığı sağlık istatikleri yıllığından alınan sağlık göstergeleri bulunmaktadır.

İngiltere'nin Kişi Başına GSYH'sı 42,300\$ düzeyinde iken, Türkiye’nin ise 9,043\$ düzeyindedir. İngiltere'nin kişi başına GSYH'sı Türkiye'nin yaklaşık beş katıdır.

İngiltere'nin 0-14 yaş nüfusu \%18,6 iken, Türkiyenin ise \%23,1 düzeyinde olduğu görülmektedir. Bu durum İngiltere'ye karşın Türkiye'nin oldukça genç bir nüfusa sahip olduğunu göstermektedir. Genç nüfustaki bu durum 60-65 yaş arası tam tersi bir durumdadır. İngiltere'nin 60-65 yaş arası nüfusu \%18,31 düzeyinde iken, Türkiye'de ise \%9,1 düzeyindedir. İngiltere nüfusunun yaşlı olması bakım hizmetlerinin ve koruyucu sağlık hizmetlerinin önemini göstermektedir. 
Tablo'da yataklı tedavi hizmetlerinin MR ve BT cihaz rakamlarını incelediğimizde Türkiye'nin MR ve BT cihaz donanımı toplam oranı Ingiletere'ye oranla cihaz donanımı fazladır. Bu durumda Türkiye'nin tedavi hizmetlerine daha fazla dikkat çekitiği İngiltere'nin ise koruyucu hizmetlere önem verildiği saptanmaktadır.

İngiletere'de hekime müracat sayısı 4 iken Türkiye'de bu rakan 9,8 olatak görülmektedir. Bu durum İngiletere'deki zorunlu sevk hizmetinin etkili olduğunu göstermektedir. 10.000 kşiye düşen yatak sayısı olarak Türkiye ve İngitere hemen hemen aynı durumdadır.

Hastanın hastanede kalış süresi hastanede verilen sağlık hizmetinin kalitesinin en belirgin özelliği olarak kullanılmaktadır. Bu nedenle bir sağlık hizmeti için hastanelerde kalış süresinin az olması beklenmektedir. Hastanelerde yatan hasta ortalama kalış günü 2019 verilerinde İngiltere'de 6,8 Türkiye'de 4,2 gün görülmektedir.

1.000 kişiye düşen günlük antibiyotik kullanım oranı İngiltere'nin 18,0 olarak, Türkiye'nin 31,9 olarak görülmektedir. Bu sayılar Türkiye'nin ayakta tedavide yaygın, İngiltere'nin ise koruyucu hizmette iyi olduğunu tesip edilmektedir.

Sağlık verilerinde belirtildiği gibi sağlık finansmanları ile sağlık hizmet sunumlarına bakılarak, ülkelerin sağlık kalitesini ve verimliliğini belirleyen unsurlar değildir. Verilere ve istatistiklere bakıldığında dikkatle vurgulanan sağlık performans değerlendirmesinin yanında sağlık hizmetlerinin özelliklerinin yanı sıra adaletli sistem anlayışı, verimlilik ve kalite vb. faktörlerde önem taşımaktadır. Fakat genel olarak bir değerlendirme için ülkeler arası bir kıyas tablosu ile bu karşılaştırmayı yapmamız mümkündür.

\section{SONUÇ VE ÖNERILER}

Türkiye gelişmiş devletlerin seviyesine ulaşmak için bir sistem arayışı içerisinde olmuştur ve bu oluşum devam etmektedir. Dolayısı ile 60 yıllardan sonra İngiltere sağlık sistemleri baz alınarak sağlık hizmetlerinde bir tür devlet politikası olan sosyalizasyon denemelere başlamıştır. Ancak bu denemden pek başarılı olamamıştır. Bu da gösteriyor ki toplum olarak gelişmiş olan toplumların seviyesine ulaşamadığımızı gösterir. Nitekim değişen dünya şartlarında sağlık alanında da büyük değişiklikler meydana gelmektedir. Bu da bütün ülkelerin sağlık politikalarının ona göre geliştirmek zorunda kaldığı gözükmektedir. Nitekim Türkiye 2002 yılından sonra sağlık dönüşüm politikaları ile yeni bir sistem uygulamasına geçmiştir.

Ulusal Sağlık Sistemi olarak bilinen İngiltere sağlık politikaları, kiliselerden başlayıp bu zamana kadar birçok değişikliğe uğramıştır. 1948'den başlayarak bugüne kadar siyasal güçlerin planları ve küresel ekonomik gelişmelere bağlı olarak İngiltere'de sağlık politikalarının göstermiş olduğu değişim görülmektedir. Ulusal Sağlık Sisteminden yararlanmakta olan bireylerin sağlık finansmanını neredeyse tamamını vergilerden karşılanmaktadır. Finansmanın vergilerden karşılanması devlet açısından bir sorun haline gelmiştir. Bu nedenle son yıllarda NHS'nin yapısal ve işlevsel problemleri ortaya çıktığı gözlenmektedir. İngiltere'nin AB'den ayrılması ile birlikte oluşacak sorunları gelecek yıllarda sağlık hizmet sunumu ve sağlık finansman gibi durumlar netliğe kavuşacaktır.

Bu çalışmada, politika kavramının genel yapısı ile sağlık kavramı ele alınmış ve araştırmanın ana konusu olan sağlık politika kavramı yakından incelenmiştir. Sağlık politikası olarak dünyada ki mevcut durum ve gelişmelere göz atılmış, ülkemizin bu alanda ki mevcut durumu incelenmiş ve kıyaslama yapabilmek adına İngiltere'nin gelişimi incelenmiştir.

Çalışmamızda incelediğimiz Türkiye ve İngiltere sağlık hizmetlerinin farklı açılardan birbirlerine üstünlükleri olduğu gibi, farklı dezavantajlı durumları ve riskleri de bulunmaktadır.

Türkiye'de sevk zincirinin zorunlu olarak uygulanması ve sağlık politikalarının daha fazla halkçı olması, piyasalaşmaktan vazgeçilmesi önerilmektedir.

\section{KAYNAKÇA}

Abdulaziz, G., (2017). Türkiye'de sağlık sisteminin finansmanı ve İngiltere ile karşılaştırması. Marmara Sosyal Araştırmalar Dergisi, 12, 18-33.

Aktel, M. Altan, Y. Kerman, U. Eke, E., (2013). Türkiye'de sağlık politikalarının dönüşümü: programı: Sağı̆ık Bakanlığı'nın taşra örgütlenmesi üzerinden bir analiz. Sosyal Bilimler Dergisi, 15(2), 34-58.

Bevan, G. Karanikolos, M. Exley, J. Nolte, E. Connolly, S., Mays, N. (2014). The four health systems of the United Kingdom: how do they compare summary report. The Health Foundation, file:///C:/Users/Tun\%C3\%A7/Downloads/Four-health-systems-of-the-united-kingdom-how-do-theycompare.pdf.

Davuthan, G., (2011). Sağlık hizmetlerinde küresel reform yaklaşımları. Sosyal Siyaset Konferansları, 60, 323-365.

Durmuş, G. Selin, E., Dilruba, I. (2018). Kamu özel otaklığı bağlamında şehir hastanelerinin değerlendirmesi. Sosial Sciences Studies Journal, 19, 2235-2243.

Engels, F., (1987). The condition of the working class in England. London; Penguin Classics. 34.

Ertuğrul, A., Sabiha, K. (2012). Türkiye'de sağlık sektöründe kamu özel ortaklığı modeli. Süleyman Demirel Üniversitesi İktisadi ve İdari Bilimler Fakültesi Dergisi, 3, 25-51. 
Ferimah, Y., Derya, G. (2011). Devlet/Kamu üzerine yeniden düşünmek. Sağlık Alanında Kamu-Özel Ortaklığı Sempozyumu, 6-7 Mayıs, 29-83.

Gazanfer, A., Hatice, G. (2006). Birleşik Krallık'ta ulusal sağlık hizmetinin öyküsü. Toplum ve Hekim, 21(5/6), 335-343.

Ham, C., (2005). Does the district general hospital have a future. Education and Debate, Erişim: https://www.ncbi.nlm.nih.gov/pmc/articles/PMC1298863/.

Hermann, C., (2010). Kapitalizmde sağlık, sağlıksızlık semptomları. L. Panitch ve C. Leys (Eds.), Haskan, U. (Çev.). London: Merlin Press.

Hilmi, Ç., (2009). Sağlık ekonomisi ve Türkiye'de sağlık hizmetlerinin yeniden yapılandırılması. Doktora Tezi, Dokuz Eylül Üniversitesi, İzmir. Erişim adresi: http://acikerisim.deu.edu.tr:8080/xmlui/bitstream/handle/20.500.12397/12234/236083.pdf?sequence=1\&isAllowed=y.

Hüseyin, İ. Betül, S., Handan, E. (2016). Sağlık politikası kavramı ve Türkiye'de sağlık politikalarının incelenmesi. Selçuk Üniversitesi Sosyal ve Teknik Araştırmalar Dergisi, 12, 176-186.

Jakubowski, E., Busse, R. (1998). Health Care Systems in the EU [A comparative Study, EuropeanParliament, http://www.europarl.europa.eu/workingpapers/Saco/Pdf/101_En.Pdf. (Erişim Tarihi: 04/2019).

Koray, K., (2011). Sağlık hizmetlerinin örgütlenmesinde kamu-özel ortaklığı. Ankara Üniversitesi Siyasal Bilgiler Fakültesi Dergisi, 66(3), 217-262.

Leys, C. (Çev.). Meltem, K. (2007). Avrupa'da ve Türkiye'de Sağlık Politikaları, İletişim Yayınları, 6. Baskı, 95-110.

Mooney G, C., (2012). Ulusların Sağlığı Yeni Bir Ekonomi Politiğe Doğru. Yordam Kitap, 2. Baskı, 97-110.

Mustafa, Ö. Serhat, B., Abdullah, Y. (2004). Kamu yönetiminde yeni yaklaşımlar ve bir yönetişim faktörü olarak yerel yönetimler, 23-80. Erişim: https://www.researchgate.net/publication/296651128_KAMU_YONETIMINDE_YENI_YAKLASIMLAR_VE_BIR_YONETISIM_FAKTORU_OLARAK_YE REL_YONETIMLER.

Osman, G. Yusuf, Ö. Mualla, A., ve İskender G., (2008). Sağlık21: DSÖ Avrupa bölgesi için herkese sağık politikası çerçevesi. Aile ve Toplum Dergisi, $1,711,3-4$.

Peckham, S., (2014). Accountability in the Uk healthcare system: an overview. Healthcare Policy, 15, 154-162.

Resmî Gazete, (2018). Türk Tabipler Birliği, Tabipler Türk Tabipleri Birliği Tıp Dünyası Gazetesi'nin Ekidir. 34(8323), 1-9.

Selin E, A., (2012). Ulusal Sağlik Sistemleri ve 1980 Sonrasinda Türkiye'de Sağlikta Dönüşüm Politikalarinin İncelenmesi ve Değerlendirilmesi, Doktora Tezi, Gazi Üniversitesi, Ankara, Erişim:

https://dspace.gazi.edu.tr/bitstream/handle/20.500.12602/176682/2276e114cc688829629f9852471937bf.pdf?sequence=1\&isAllowed=y.

Seher Nur, S., (2011). Türkiye'de sağlıkta dönüşüm programı öncesi ve sonrasında sağılık hizmetlerinin sunumu, finansmanı ve sağılık harcamaları. Maliye Bakanlığı Strateji Geliştirme Başkanlı̆̆ı, https://ms.hmb.gov.tr/uploads/2019/09/Kitap-414.pdf.

Sedat, B., Gökhan, A. (2019). Kamu hastaneler birliğinin yapılmasının sağlık hizmeti sunu süreçlerine etkisinin yönetici ve çalışanlar açısından değerlendirmesi. İşletme Bilim Dergisi, 7(1), 153-167.

Szreter, S., (1997). The importance of social intervention in britain's mortality decline a re-interpretation of the role of public health,1, 1-37. The New Nhs. Department of Health. C. 1850-1914.

Uysal, K. Yakup, A. Mehmet, A. Erdal, E. (2012). Sağlık hizmetlerinde kamu özel ortaklı̆̆ı uygulaması. Süleyman Demirel Üniversitesi İktisadi ve İdari Bilimler Fakültesi Dergisi, 17(3), 5-14.

Ünal, E., (2011). Sağlıkta dönüşümün aracı genel sağlık sigortası. Yüksek Lisans Tezi. Ankara Üniversitesi Sosyal Bilimler Enstitüsü.

Vizard, P., Obolenskaya, P., (2015). The coalition's record on health: policy, spending and outcomes 2010-2015. Social Policy in a Cold Climate. 16(2), 1-160.

Zafer, Ö., (2006). Sağlıkta Dönüşüm Hekimliği. Toplum Hekim Büteni, 25(2), 2-3,

http://www.thb.hacettepe.edu.tr/arsiv/2006/sayi_2/baslik1.pdf. 